Annals of Warsaw University of Life Sciences - SGGW

Land Reclamation No 39, 2008: 3-20

(Ann. Warsaw Univ. of Life Sci. - SGGW, Land Reclam. 39, 2008)

\title{
The changing sediment loads of the world's rivers ${ }^{1}$
}

\author{
DES E. WALLING \\ Department of Geography, University of Exeter U.K.
}

\begin{abstract}
The changing sediment loads of the world's rivers. This contribution reviews available evidence of recent changes in the sediment loads of the world's rivers and identifies the key drivers of such change. Land clearance, land use change and other facets of catchment disturbance, soil conservation and sediment control programmes and dam construction are shown to have resulted in significant recent changes in the sediment loads of many world rivers. Some rivers have been characterized by significant increases in sediment load, whereas others show significant decreases. Interpretation of the resulting trends requires consideration of aggregation and storage and buffering effects within a river basin, such that the downstream response of a river may not clearly reflect the changes occurring in the upstream basin and in the loads of tributary rivers.
\end{abstract}

Key words: Suspended sediment loads, trends, world rivers, anthropogenic impacts, reservoir trapping, buffering effects, global land-ocean sediment transfer.

\section{INTRODUCTION}

The International Geosphere Biosphere Programme (IGBP) initiated by ICSU in 1987 (see Steffen et al. 2004), as well as a number of related initiatives, have focused increasing attention on the changes in the functioning of the Earth

\footnotetext{
${ }^{1}$ This contribution draws heavily on an invited keynote paper presented by the author at the 10th International Symposium on River Sedimentation, held in Moscow, Russia in August, 2007.
}

system caused by human activity and on the problems associated with the sustainable management of this changing system over the coming centuries. Much of this attention has been directed to the increased emission of greenhouse gases, leading to climate change. However, as recognized by the IGBP, anthropogenic pressure must be seen as the cause of many other facets of global change. These include major changes in vegetation cover and land use across the earths surface, wide ranging disturbance of that surface by infrastructure development and mineral exploitation and modification of the hydrological cycle caused by water resource exploitation. In the latter context it is estimated that dams currently intercept more than $40 \%$ of the annual water discharge from the continents (Vörösmarty et al. 2003). Such changes in the condition of the land surface of the earth and the flow of its rivers, as well as ongoing climate change, can be expected to have exerted a significant influence on the sediment loads of the world's rivers. Sediment loads will be sensitive to both increases and reductions in land erosion caused by human activity, as well as changes in river flows and sediment transport caused by water resource exploitation, construction of dams and other human uses of river systems. The 
temporal trajectories of these anthropogenic impacts will have varied across the land surface of the globe in response to the history of human exploitation of the landscape. In some areas of the 'old world', for example, forest clearance and the expansion of agriculture can be expected to have resulted in changing sediment loads as far back as several millennia, whereas in areas of the 'new world' equivalent changes may have occurred within the last two centuries. Nevertheless, the accelerating pace of human impact in many areas of the world means that the changes in the sediment loads of its rivers are likely to be intensifying.

A)

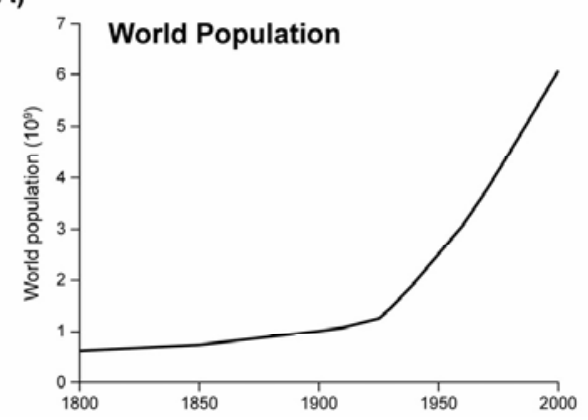

C)

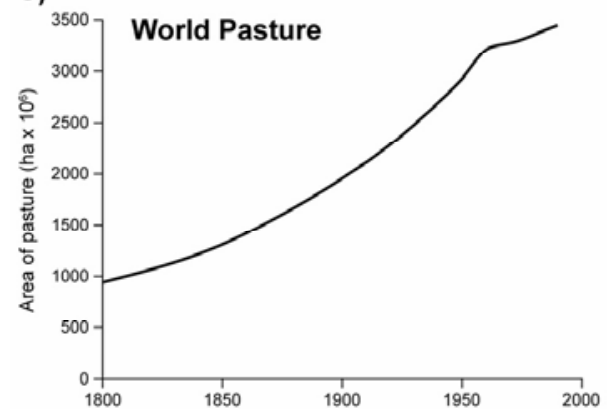

Figure 1 emphasizes the acceleration of several likely drivers of changing sediment loads over the past century. Population growth can be viewed as a surrogate for many components of anthropogenic pressure, including land clearance, intensification of land use, mineral exploitation and infrastructure development, whilst the expansion of cropland and pasture and the destruction of tropical forests provide a more direct measure of changing land cover. The significance of recent change is particularly apparent in the case of water resource development, which itself links closely with population growth. Almost all of the

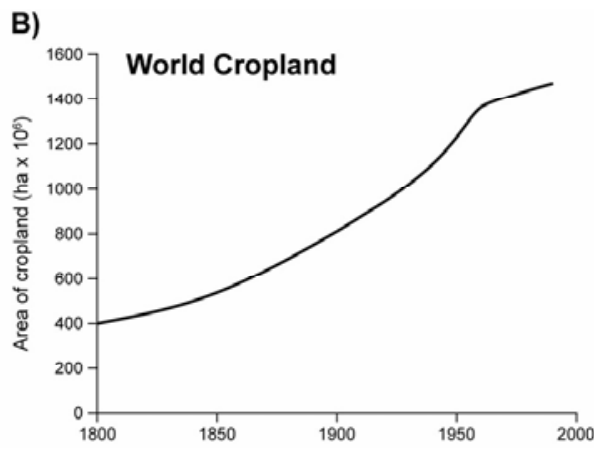

D)

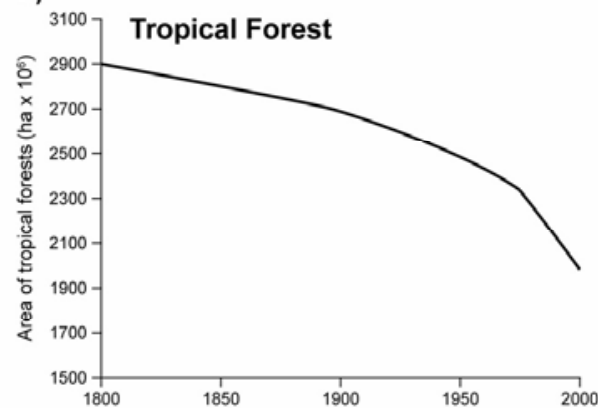

FIGURE 1. Changes in world population, the global area of cropland and pasture, and the extent of the world's tropical forest over the past 200 years. (Based B and C on Goldewijk 2001 and D on Roper and Roberts 1999) 
world's major reservoirs were, for example, constructed during the past 60 years.

The significance of potential changes in the sediment loads of the world's rivers is wide ranging. From a global perspective, changes in land-ocean sediment transfer will result in changes in the global biogeochemical cycle, since sediment is important in the flux of many key elements and nutrients. Equally, this transfer will also reflect the intensity of soil erosion and land degradation and thus the longer-term sustainability of the global soil resource. At the regional and local scales, changes in the sediment load of a river can give rise to a range of problems. Excessive sediment loads can result in accelerated rates of sedimentation in reservoirs, river channels and water conveyance systems, causing problems for water resource development and in maintaining navigable waterways and harbours, as well as in adverse impacts on aquatic habitats and ecosystems, including offshore coral reefs Conversely, reduced sediment loads can result in the scouring of river channels and erosion of delta shorelines as well as reduced nutrient inputs to aquatic ecosytems, particularly lakes, river deltas and coastal seas.

This contribution provides a brief review of available empirical evidence of recent changes in the annual suspended sediment loads of the world's rivers, with a view to evaluating recent trends and assessing their sensitivity to recent environmental change and other anthropogenic impacts, identifying the key drivers of change, and highlighting some of the complexities associated with linking changes in the sediment output from a river basin to the changes occurring within that basin.

\section{EVIDENCE OF CHANGE}

A clear example of the non-stationary nature of the recent record of suspended sediment transport by a major world river and the potential importance of both human impact and climate change is provided by the recent changes in the suspended sediment discharge of the lower Huanghe or Yellow River in China (Fig. 2A). In the literature, the mean annual suspended sediment load of the Yellow River is frequently cited as $1.6 \mathrm{Gt}$ year ${ }^{-1}$ (e.g. Shi et al. 2002). This value is based on the available records extending through to the 1980s for the long-term monitoring station at Sanmenxia, which is located some $800 \mathrm{~km}$ from the delta, where the river flows out of the loess region and enters the North China Plain. The equivalent value for the downstream monitoring station at Lijin, which is located about $40 \mathrm{~km}$ from the delta and which provides a more meaningful estimate of sediment delivery to the ocean is $1.08 \mathrm{Gt}$ year $^{-1}$. Recent years have, however, seen a significant reduction in the load measured at Lijin, with this falling to ca. $0.8 \mathrm{Gt}^{-1} \mathrm{yr}^{-1}$ in the $1980 \mathrm{~s}$, and to ca. $0.4 \mathrm{Gt} \mathrm{year}^{-1}$ in the 1990s (Fig. 2A). Available information suggest that the load at Lijin has reduced still further in the early years of the current century and may now be as low as $0.15 \mathrm{Gt}_{\text {year }}{ }^{-1}$. Based on these data, the current sediment load at Lijin can be seen to be almost an order of magnitude lower than that documented for the period prior to about 1980.

Simple trend analysis applied to the records of water and suspended sediment discharge for the Yellow River at Lijin in Figure 2A, using linear regression to establish trend lines, provides clear 
A) Yellow River at Lijin, China, $1950-2000$
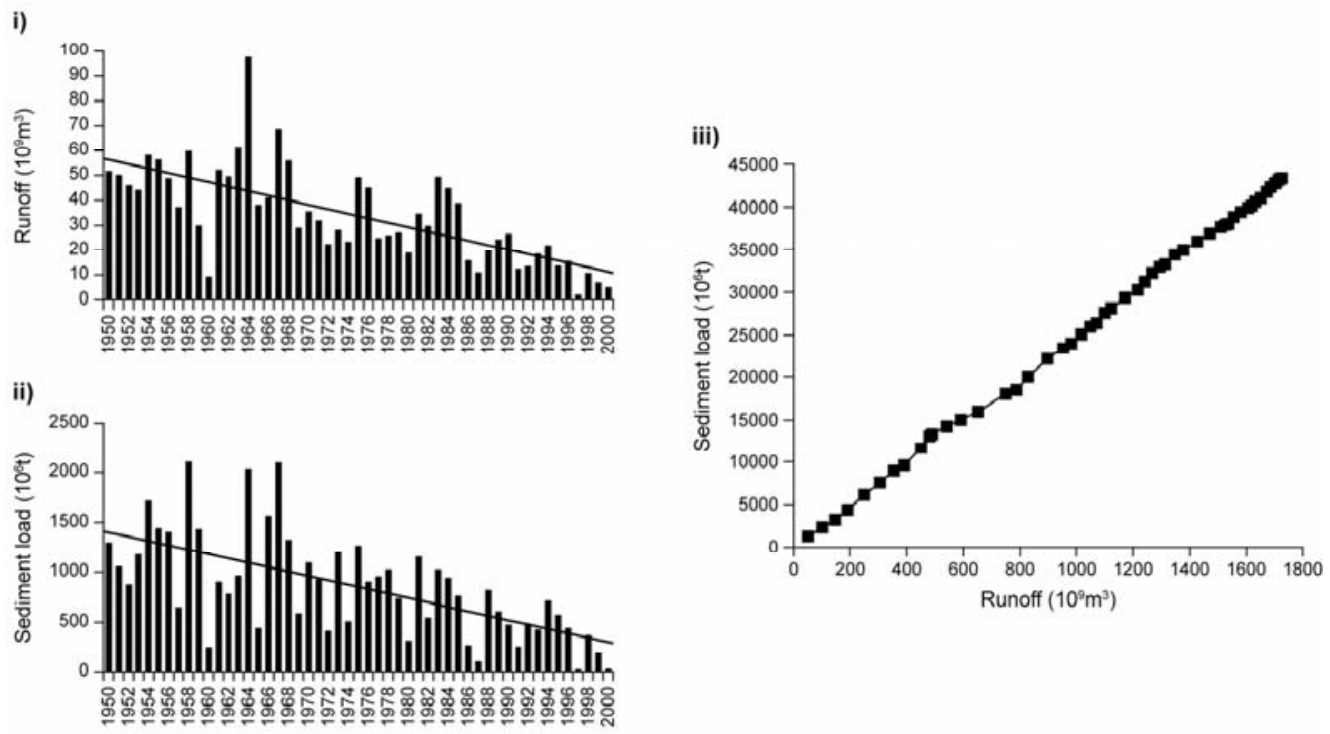

B) Rio Magdalena at Calamar, Colombia, 1972 - 1998

i)

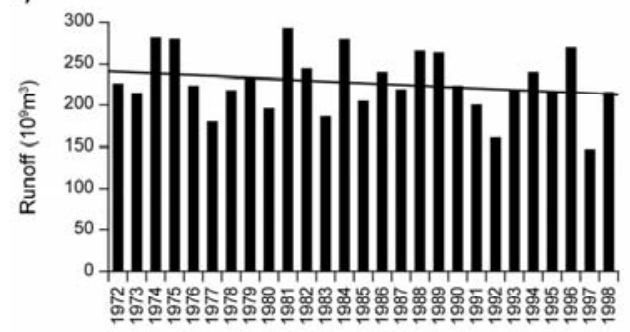

ii)
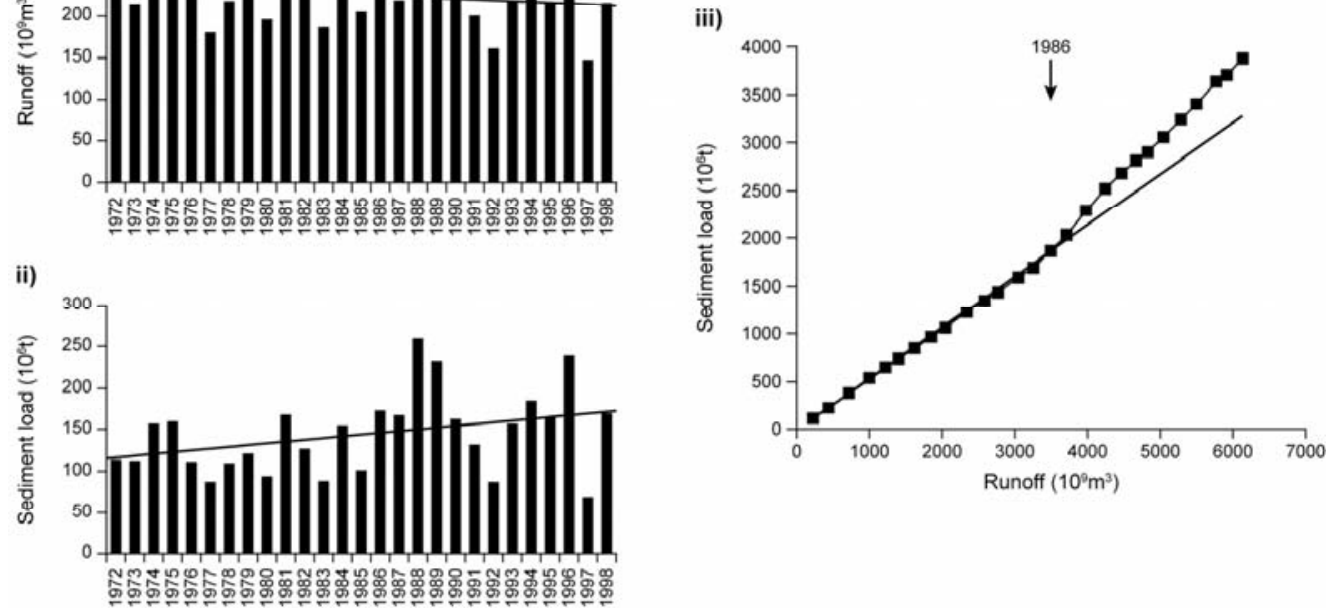

FIGURE 2. Recent changes in the suspended sediment loads of the Lower Yellow River, China (A) and the Rio Magdalena, Colombia (B), as demonstrated by the time series of annual water discharge (i) and annual sediment load (ii) and the associated double mass plots (iii) 
evidence of a statistically significant $(\mathrm{P}>99.9 \%)$ reduction in both water and sediment load over the past 50 years. The lack of any clear break in the double mass plot (Fig. 2Aiii), a tool frequently used to identify changes in the sediment response of a river (e.g. Walling 1997), suggests that both the runoff and sediment response have responded to similar controls. The progressive reduction in both the water discharge and suspended sediment load of the Yellow River, demonstrated by Figure 2A, is in part a response to climate change, and, more particularly, reduced precipitation over the central region of the catchment, but it is primarily a reflection of human impact and, more particularly, increasing water abstraction (as evidenced by the greatly reduced flows in Fig. 2Ai), sediment trapping by an increasing number of both large and small reservoirs and an extensive programme of soil and water conservation, aimed at both improving local agriculture and reducing sediment inputs to the river, where siltation poses major problems for effective flood control and water use in the lower reaches of the basin.

A contrasting example of the recent trend of suspended sediment load is provided by the Rio Magdalena in Colombia, South America (see Fig. 2B). This major river drains a catchment of ca $250000 \mathrm{~km}^{2}$ and accounts for ca $9 \%$ of the total sediment flux from the eastern seaboard of South America (see Restrepo and Kjerfve 2000). In this case, the time series of annual sediment loads for the period 1972 to 1998 portrayed in Figure 2Bii shows a statistically significant $(\mathrm{P}=90 \%)$ upward trend, whereas there is no significant trend in the water discharge series (Fig. 2Bi).
The increase in annual sediment load represents a response to forest clearance, land use intensification and gold mining activity within the catchment. The double mass plot clearly shows a change (increase) in the annual sediment loads after 1986, with loads increasing by about $40 \%$ over the period of record.

Any attempt to identify changes in the sediment fluxes of major rivers, such as that attempted above, is heavily dependent on the availability of reliable data. Long-term records stretching back over several decades are available for relatively few of the world's rivers. Furthermore, for many rivers with sediment monitoring programmes, the available data are inadequate for a rigorous assessment of trends in a parameter that which can be expected to exhibit significant interannual variability, even in the absence of a changing response For example, where only a few sediment samples are collected each year, these data are frequently aggregated over a long period, to construct a sediment rating curve that is applied to the water discharge record for that period. Such temporally-lumped sediment rating curves cannot represent non-stationarity in the sediment concentration record, such as might occur due to sediment trapping by upstream reservoirs or land use change within the catchment.

\section{THE KEY DRIVERS OF CHANGING SUSPENDED SEDIMENT LOADS}

\section{Land clearance for agriculture and intensification of agricultural land use}

The literature contains a vast body of empirical evidence derived from erosion plots and small catchments, which demon- 
A) Lancang River at Jinghong, China, 1963 - 1990

i)

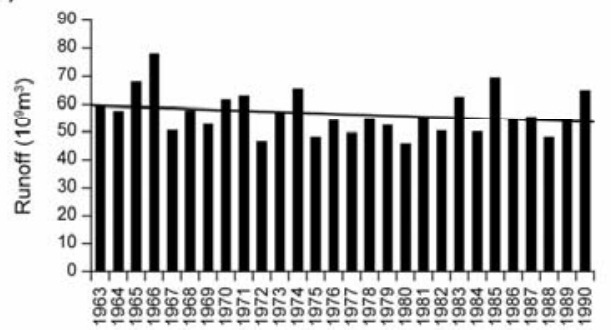

ii)
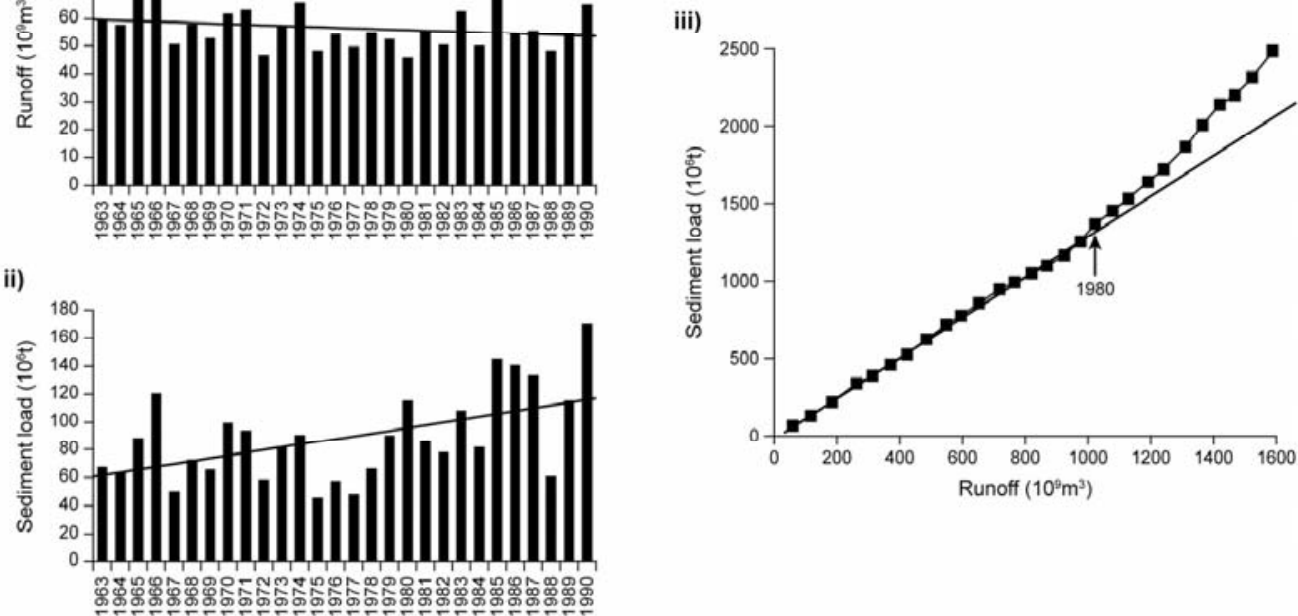

B) Yazgulem River at Motravn, Tajikistan, 1950 - 1986

i)

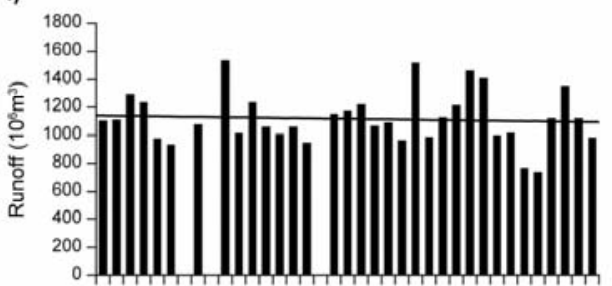

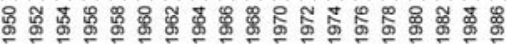

ii)
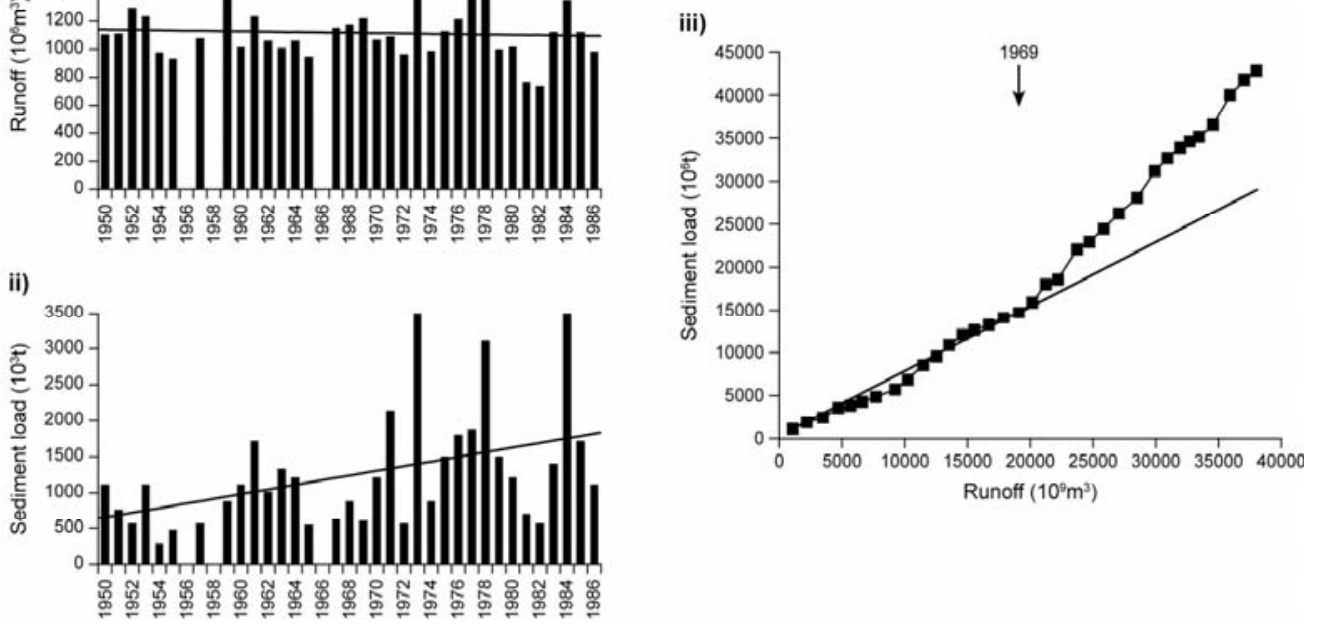

FIGURE 3. Recent changes in the suspended sediment loads of the Lancang River, China (A) and the Yazgulem River, Tajikistan (B), as demonstrated by the time series of annual water discharge (i) and annual suspended sediment load (ii) and the associated double mass plots (iii) 
strates the impact of forest clearance and related land cover change and land use activities on rates of soil loss and sediment yield. Order of magnitude increases in both rates of soil loss and sediment yield have been widely reported (e.g. Morgan 1986) and these must clearly result in increased sediment loads in rivers, whose basins have been widely affected by such changes. However, when attempting to extrapolate the evidence provided by erosion plots to larger river basins, it is important to recognise the need to take account of the 'connectivity' of the landscape to the river system, since much of the mobilised sediment may be deposited before reaching the channel network and may therefore not be directly reflected by increased sediment loads. Similar considerations apply when attempting to extrapolate the findings from small catchments to larger river basins, since a significant proportion of the increased sediment flux generated within small catchments may be deposited downstream within the channel and floodplain system of the larger basin, before reaching its outlet.

Two clear examples of recent increases in river sediment loads associated with land clearance and intensification of agricultural land use are provided in Figure 3 . Figure $3 \mathrm{~A}$ presents information for the $140.933 \mathrm{~km}^{2}$ basin of the Upper Mekong or Lancang River in China where extensive land clearance and land use change associated with rapid population growth in the 1970s and 1980s are reflected by a significant $(\mathrm{P}>95 \%)$ trend of increasing sediment loads over the period 1963 to 1990, whereas the annual runoff record showed no statistically significant trend. The double mass plot shows a clear shift towards increased sediment loads around 1980. Figure 3B presents data for the smaller $1.940 \mathrm{~km}^{2}$ basin of the Yazgulem River in Tajikistan, Central Asia. Again, the record of annual water discharge for this river shows no significant trend, but the sediment record is characterized by a significant $(\mathrm{P}=99 \%)$ increase over the period 1950 to 1986 , with the sediment load more than doubling over this period. The double mass plot suggests that this increase commenced around 1969. The catchment of the Yazgulem River is in a mountainous area and this increase in its suspended sediment load can be linked to expansion of agricultural activity, particularly livestock grazing.

\section{Catchment disturbance by infrastruc- ture development and other economic activities}

Land clearance for agriculture and subsequent intensification of agricultural land use are only one of the many ways in which human activity can change the natural vegetation cover and disturb the catchment surface, thereby increasing erosion and sediment yields. Forest cutting for timber production, mining and the development of infrastructure such as roads and settlements will frequently resultindestruction of the vegetationcover and widespread disturbance of the catchment surface and thus increased erosion and sediment loads. Two examples of the impact of such disturbance are provided in Figure 4. Figure 4A presents information on the changing sediment load of the $99.400 \mathrm{~km}^{2}$ basin of the Kolyma River in Eastern Siberia, over the period 1942 to 1989. Again, there is no significant trend in the time series of annual runoff, but that for annual suspended sediment loads 
A) Kolyma River at Srednekansk, Siberia, 1942-1989

i)
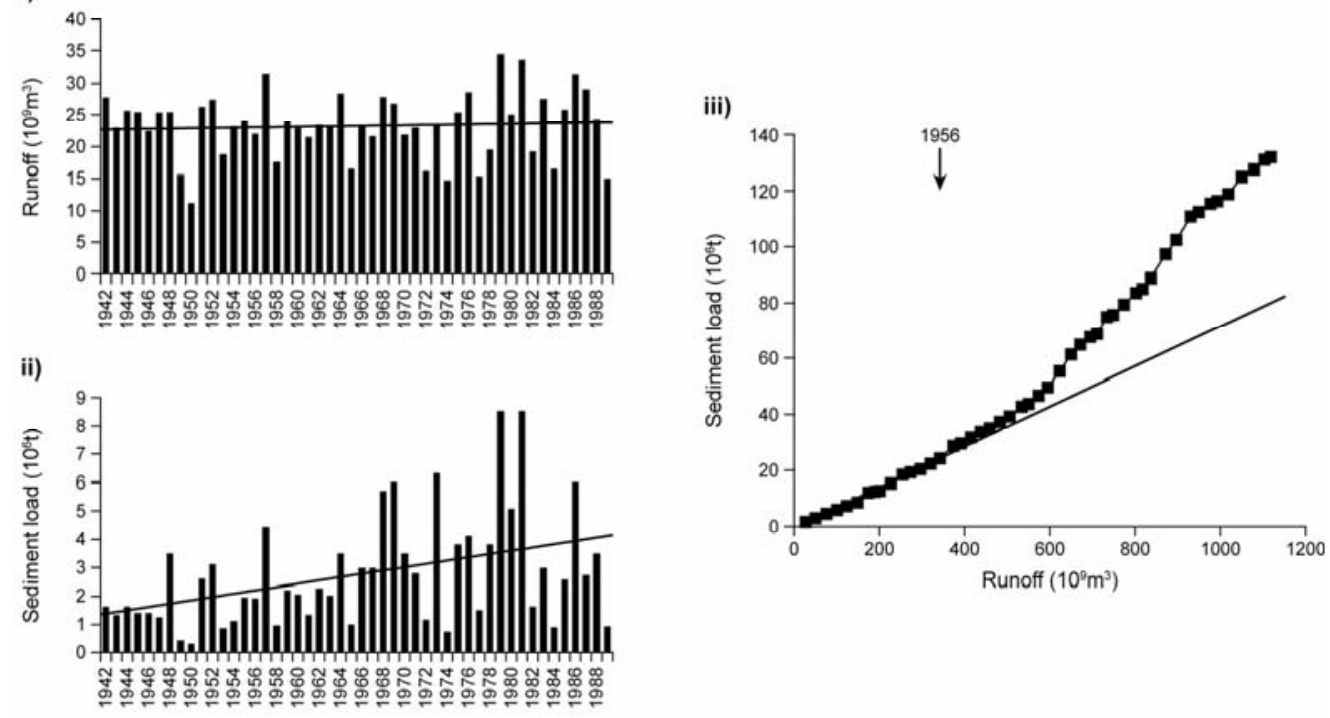

B) Bei-Nan River, Taiwan, 1948 - 2002
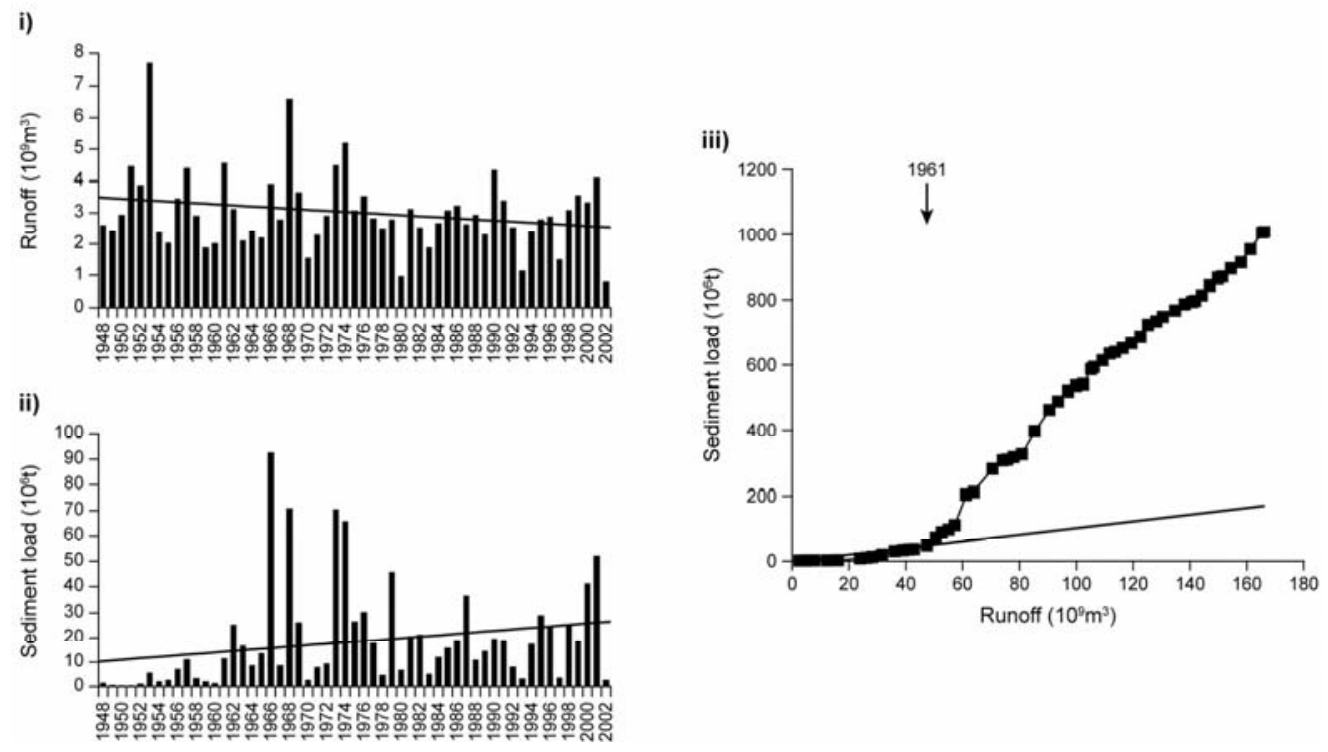

FIGURE 4. Recent changes in the suspended sediment loads of the Kolyma River, Siberia and the Bei-Nan River, Taiwan, as demonstrated by the time series of annual water discharge (i) and annual suspended sediment load (ii) and the associated double mass plots (iii) 
shows a significant increase $(\mathrm{P}>99 \%)$ over the period of record, with annual loads increasing by a factor of two over this period. The double mass plot (Fig. 4Aiii) indicates that the change in the sediment response of the basin dates from around 1956 and Bobrovitskaya (personal communication) has indicated that the primary cause of this increase was the expansion of gold mining activity within the basin, which caused major disturbance of river channels and floodplains. The example presented in Figure $4 \mathrm{~B}$ relates to the smaller $(1.584$ $\mathrm{km}^{2}$ ) mountainous basin of the Bei-Nan River in Taiwan, characterised by steep unstable slopes and tectonic instability (see Kao et al. 2005). Here, land clearance and catchment disturbance associated with road construction have caused a major increase in the annual suspended sediment load, with the double mass plot (Fig. 4Biii) suggesting that sediment loads increased by almost an order of magnitude after 1961. The time series of annual sediment loads show a statistically significant $(\mathrm{P}=90 \%)$ upward trend, but in this case the water discharge shows evidence of a statistically significant downward trend, possibly connected with increasing water abstraction. The trend shown by this river in Taiwan is likely to be mirrored by many rivers in the Pacific Rim region, draining small mountainous basins, where forest clearance and surface disturbance have been widespread in recent decades. This has important implications for land-ocean sediment fluxes, since Milliman and Syvitski (1992) have shown that this region accounts for a major proportion of the global land-ocean sediment flux.

\section{Soil conservation and sediment control programmes}

Although land use impacts on sediment loads are commonly seen as resulting in increased sediment loads, the implementation of soil and water conservation and sediment control programmes in river basins can have the reverse effect and result in reduced sediment loads, or at least reduce the increases associated with land clearance and surface disturbance. By virtue of the growing importance of soil and water conservation and sediment control programmes in many areas of the world, this component of human impact on global sediment fluxes must be assuming increasing importance. Quantitative evidence of that importance is, however, currently limited. As with land use impacts considered above, the literature provides many examples of plot and small catchment experiments, which clearly demonstrate the success of soil and water conservation measures in reducing local soil loss, but there is much less by way of quantitative evidence, which can be used to demonstrate the effects of catchment-wide soil and water conservation programmes and sediment control measures in reducing sediment fluxes from larger drainage basins. Such evidence is, however, now available for the loess region of the Middle Yellow River basin in China, where extensive soil and water conservation and sediment control programmes have been implemented over the past 30 years. In this region, much emphasis has been placed on reducing downstream sediment loads, as well as on-site soil and water conservation, in order to reduce reservoir sedimentation and to alleviate siltation 
problems along the course of the Lower Yellow River, which seriously impact on flood control measures.

Figure 5 presents information for the $4.161 \mathrm{~km}^{2}$ basin of the Sanchuan River, a tributary of the Middle Yellow River, which was the focus of extensive soil and water conservation works and sediment control measures in the 1980s. Zhao et al. (1992) reported that by the end of the $1980 \mathrm{~s}, 267 \mathrm{~km}^{2}$ of bench terraces had been constructed in the catchment, $703 \mathrm{~km}^{2}$ of highly erodible land had been planted with forests and $46.7 \mathrm{~km}^{2}$ with grass, and nine reservoirs had been constructed. Overall, nearly $30 \%$ of the basin area was actively controlled. The data presented in Figure 5 provide evidence of a significant $(P>99 \%)$ decrease in both runoff and sediment load over the period of record. The double mass plot shows a well-defined departure from its initial trend around 1970, with this departure intensifying after 1980. A comparison of the mean annual sediment loads for the periods 1957-1969 and 1980-1993 indicates that sediment yields in the latter period have decreased to only about $25 \%$ of those in the former period. As with the reduction in the sediment load of the Yellow River discussed previously, part of this decrease reflects the onset of drier conditions in the 1980s. Zhao et al. (1992) estimate that the implementation of soil conservation and sediment control measures after 1970 reduced the sediment load of the Sanchuan basin by between 36 and $41 \%$. This must be seen as a very substantial reduction for a basin of this size and a clear indication of the potential of catchment management strategies to reduce sediment loads.

\section{Sanchuan River at Xiadacheng, China, 1957 - 1993}

i)

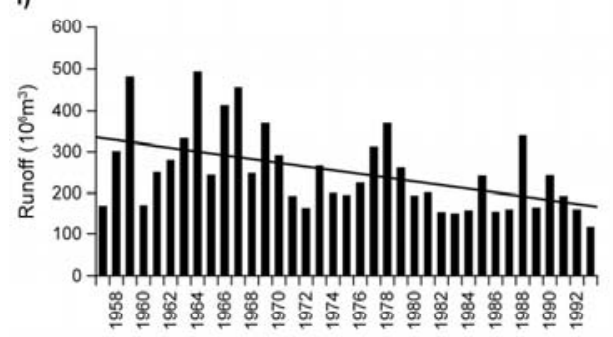

ii)

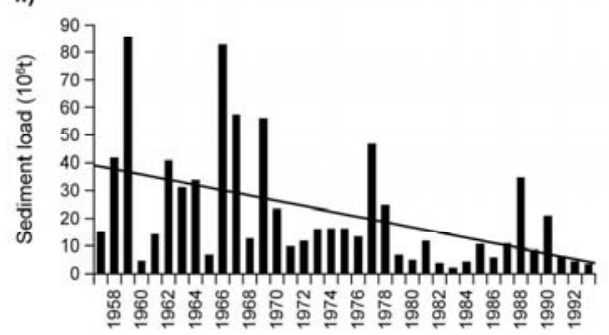

iii)

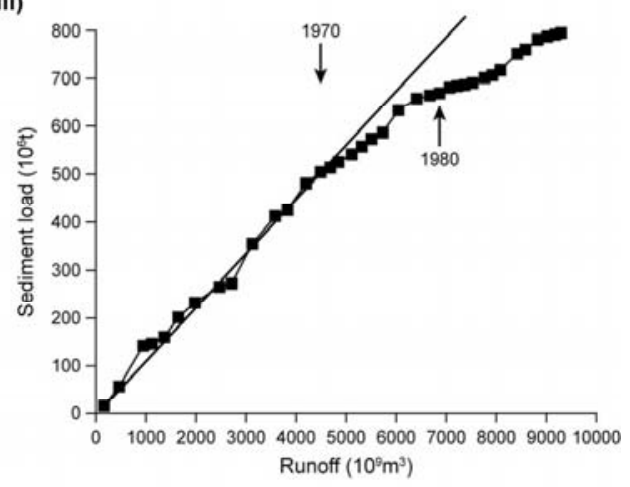

FIGURE 5. Recent changes in the suspended sediment load of the Sanchuan River, China, as demonstrated by the time series of annual water discharge (i) and annual suspended sediment load (ii) and the associated double mass plots (iii) 
Similar catchment management strategies to that employed in the Sanchuan basin were implemented in many other areas of the Middle Yellow River basin from the late 1960s and their aggregate effect in reducing sediment loads in the Lower Yellow River is evident from Figure 2A. As indicated previously, the marked reduction in sediment load shown by the sediment record from the Yellow River at Lijin reflected several factors, including the reduced precipitation over the basin, sediment trapping by large reservoirs and increased water abstraction, as well as the soil conservation and sediment control programmes considered above. In attempting to apportion the overall reduction in sediment load demonstrated by Figure 1Aii to reduced precipitation and human impact, Xu (2003) suggests that during the period $1970-1997$ ca $55 \%$ of the overall reduction in the sediment load transported by the Lower Yellow River could be attributed to human impact and ca $45 \%$ to reduced precipitation. Looking more specifically at the effects of human impact in reducing sediment input to the Lower Yellow River from the Middle Yellow River Basin during the 1980s, Mou (1996) estimates that soil conservation works were responsible for reducing the annual load by ca. $176 \mathrm{Mt}$, whereas sediment control measures and reservoir siltation generated a reduction of 124 Mt and thus soil conservation measures accounted for almost $60 \%$ of the reduction due to human impact.

\section{Sediment trapping by dams and removal through water abstraction}

Dams and their associated reservoirs now represent a key component of water resource development in many areas of the world and dams have been constructed on many of the world's rivers, in order to provide storage for water supply, irrigation, flood control and power generation. Most dams are effective sediment traps and therefore result in significant reduction in downstream sediment fluxes. Figure 6, which is based on world-wide data for the storage associated with 'large' dams, defined as those

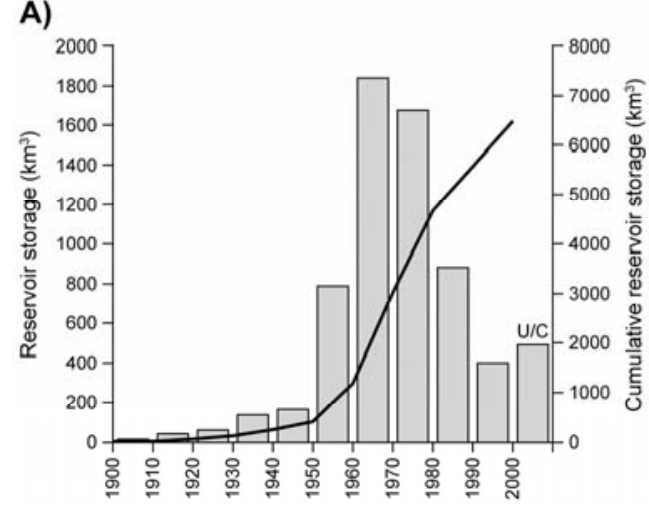

\section{B)}

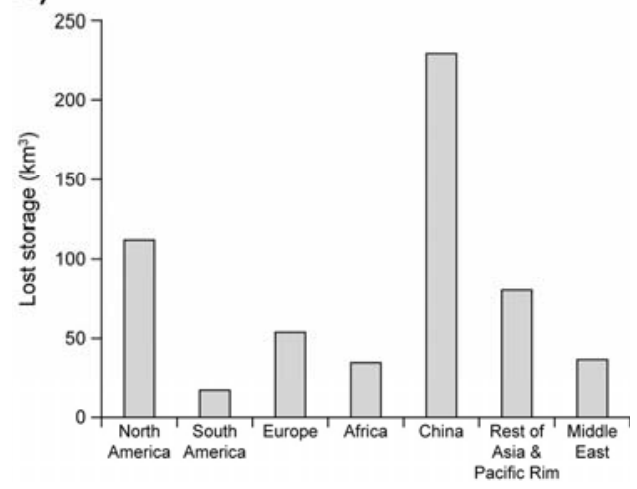

FIGURE 6. The growth of reservoir storage capacity over the past century and that under construction and planned for the period 2000-2010 (A) and the global distribution of storage lost to sedimentation to date (B). Based on data from White $(2001,2005)$ and Morris $(2005)$ 
over $15 \mathrm{~m}$ in height, provides information relating to the growth of reservoir storage capacity over the past 100 years and currently under construction (UC), and emphasizes that dam construction is a relatively recent phenomenon. Most of the current storage was constructed between the 1950s and 1980s, with much of this being added during the 1970s and 1980s. Figure 6B provides information on the cumulative volume of storage lost to sediment deposition, and thus the total amount of sediment intercepted by dams, in different areas of the world. Asia, and more particularly, China stand out as the area of the world where dams are likely to exert the maximum impact on sediment loads. Dams are frequently associated with flow regulation and water diversion for irrigation and such diversions can further reduce downstream sediment fluxes.

Figure 7 provides two very clear, although somewhat different, examples of the impact of dam construction in reducing the sediment load of major world rivers, in this case the River Indus and the River Danube. As described by Milliman et al. (1984), exploitation and control of the River Indus for irrigation and water supply, flood control and hydropower generation commenced in the 1940s with the building of numerous barrages and irrigation channels and two major dams, the Mangla Dam on its tributary the Jhelum River, and the Tarbela Dam on the main Indus near Darband were completed in 1967 and 1974, respectively. The impact of these developments on the annual discharge and sediment load of the River Indus is clearly evident on Figure 7A. Both show a marked and progressive decline over the period of record, with recent annual suspended sediment loads being only about $15 \%$ of those in the 1930 s. Most of the sediment load of the River Indus is generated in the upper part of its basin and the downstream diversion of water for irrigation and trapping of sediment behind dams and barrages causes the sediment load to progressively reduce through the middle and lower reaches of the river. In the case of the River Danube (ca $800.000 \mathrm{~km}^{2}$ ), the time series of annual suspended sediment loads again shows a statistically significant reduction over the period of record, with current sediment loads being only approximately one third of those at the beginning of the period of record. Most of this reduction occurred since the 1960s and is linked with the construction of reservoirs and control structures on both the main river and its tributaries, including the closure of the Iron Gate Dam on the main river in the early 1970s. Although these dams have had an important effect in reducing sediment loads through sediment trapping, they have much less effect on the annual water discharge and in contrast to the River Indus, Figure 7(i) shows no evidence of a significant trend in the time series of annual runoff over the same period.

The precise magnitude of the reduction in the sediment load cased by dam construction will reflect a number of factors, including the proportion of the river's flow that is withdrawn for consumptive use and the nature of the water use. Where dams are used for flood control or hydropower production, a large proportion of the water stored will be subsequently released and the river's ability to transport sediment will 
i)

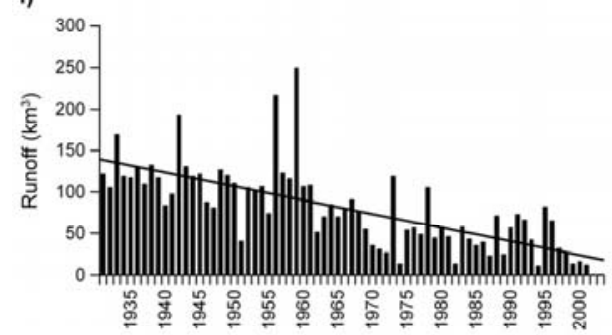

ii)

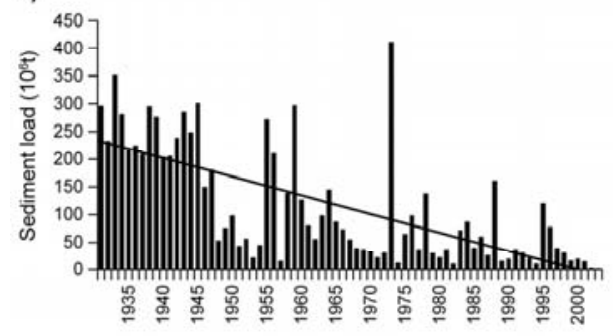

iii)

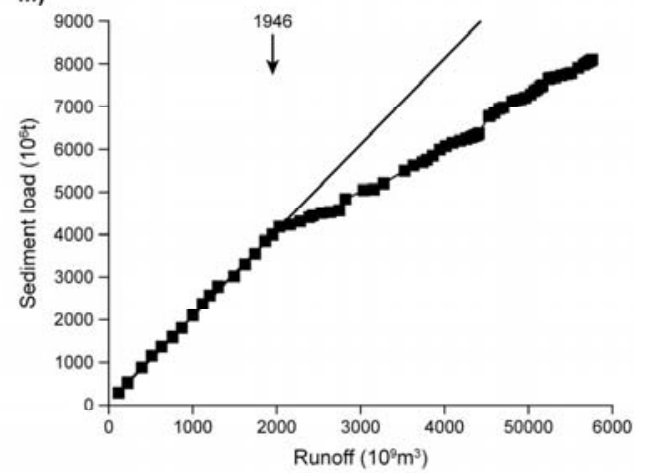

B) Danube River at Ceatal-Izmail, Romania, 1931 - 2004

"

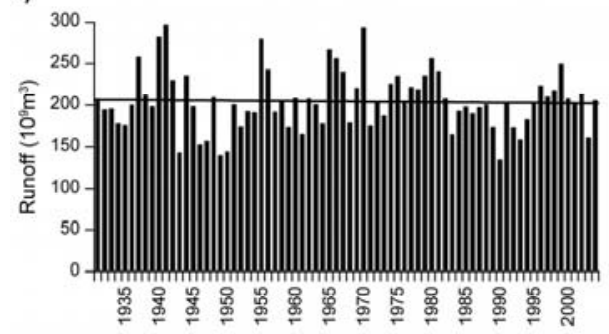

ii)
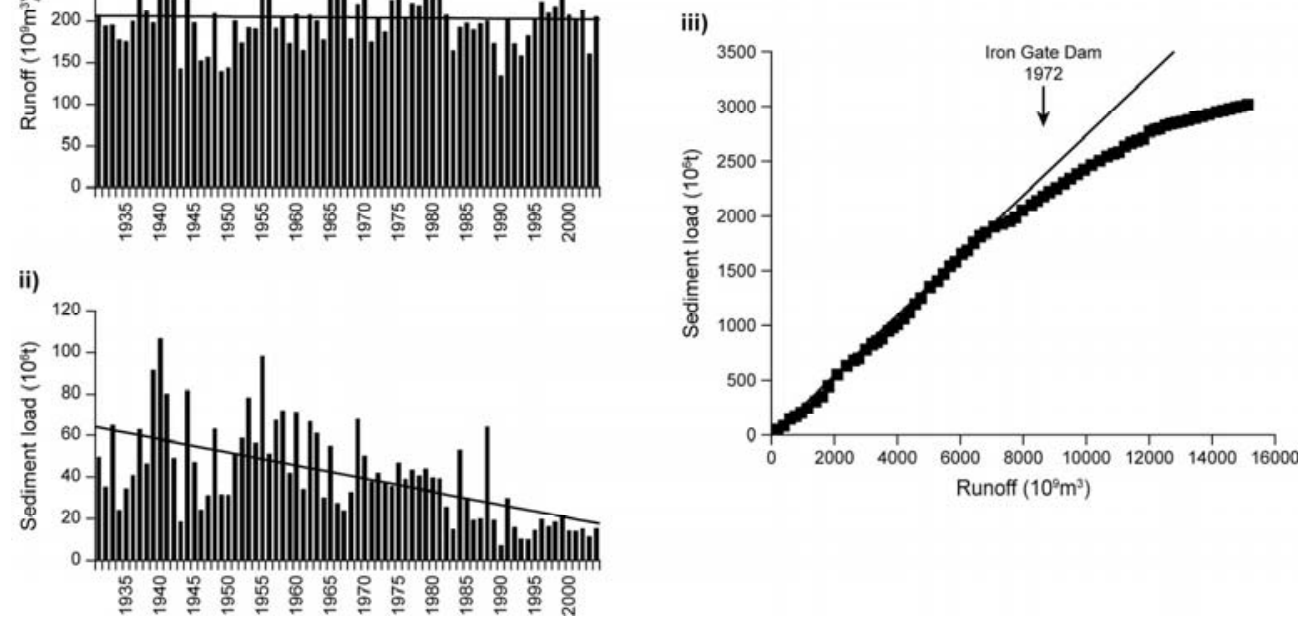

FIGURE 7. Recent changes in the suspended sediment loads of the River Indus, Pakistan (A) and the River Danube, Romania (B), as demonstrated by the time series of annual water discharge (i) and annual suspended sediment load (ii) and the associated double mass plots (iii). Data for the River Indus compiled by Professor John Milliman, Virginia Institute of Marine Science, USA 
be maintained, at least partially, even though the sediment available for transport may be reduced, due to deposition in the upstream reservoir. Where, however, much of the stored water is diverted for irrigation or water supply, the flow in the river may decline markedly and its capacity to transport sediment will also be greatly reduced. It is also important to recognize that an estimate of the amount by which the downstream sediment load of a river is reduced due to sediment trapping behind the dam is not directly equivalent to the reduction in the sediment load at the basin outlet, particularly where the dam is a considerable distance from the sea. Under pre-dam conditions a significant proportion of the trapped sediment may not have reached the sea, but would have been deposited within the channel-floodplain system. Thus, although current estimates suggest that of the order of $25 \mathrm{Gt}$ year ${ }^{-1}$ of sediment are trapped by large dams each year, the associated reduction in the land-ocean sediment flux will be very considerably less. Furthermore, in some rivers, the reduced sediment load below the dam could be, at least partly, offset by remobilisation of sediment from alluvial storage downstream (e.g. Phillips et al. 2004).

\section{Sediment Removal from Rivers}

Although the trapping of sediment behind dams and the loss of sediment associated with the diversion of flow for irrigation and other water uses are likely to represent the main causes of reduced sediment transport through river systems, it is important to recognise that in many areas of the world, particularly in developing countries, extraction of sand from river channels for use in the construction industry may represent a significant component of the sediment budget. Marchetti (2002), for example, suggests that as much as $2 \mathrm{Mt}$ of sediment are extracted each year from the central area of the Po Basin in Northern Italy. It is often difficult to obtain accurate estimates of the quantities of material involved, since much of the sand may be removed illegally without the required license. In the case of the Middle and Lower Yangtze basin in China, Chen et al. (2006) report that in-channel sand extraction became an important industry in the late 1980s, with individual dredgers being capable of removing up to $10.000 \mathrm{t}$ day $^{-1}$. They estimate that the quantity of sediment extracted could have been as high as $80 \mathrm{Mt}^{\text {year }}{ }^{-1}$ in the late $1990 \mathrm{~s}$ and Wang et al. (in press) suggest that as much as $110 \mathrm{Mt}^{\text {year }}{ }^{-1}$ of sediment are currently being extracted from the entire Yangtze system.

As in the case of sediment trapped behind dams, it is difficult to relate the quantities of sand extracted to reductions in the sediment load of the river, since not all of the sediment might have been in active transport. However, there is increasing evidence that such 'sand mining' could result in a significant reduction in the sediment load of the rivers involved. In the case of the Yangtze River in China, Chen (2004) suggests that along with sediment trapping by dams and the effects of soil conservation and sediment control programmes, 'sand mining' was an important cause of the recent reduction in the sediment load at the downstream measuring station at Datong, where the mean annual sediment load has reduced from ca $500 \mathrm{Mt}$ year ${ }^{-1}$ during the 1960 s and 1970 s to ca $350 \mathrm{Mt}^{\text {year }}{ }^{-1}$ in the $1990 \mathrm{~s}$. 


\section{Climate Change}

Most of the examples of recent changes in the annual sediment loads of the world's rivers introduced above relate to specific anthropogenic impacts, such as land clearance and dam construction. However, the example of the Lower Yellow River documented in Figure 2A highlights the need to recognise that climate change can also interact with these more specific anthropogenic impacts in causing changing sediment loads. In this case, a reduction in annual precipitation in recent decades had also contributed significantly to the declining sediment load. Looking more generally, it would seem clear that the anthropogenic impacts reviewed above are likely to represent the most important cause of recent changes in the sediment loads of the world's rivers, but the potential impact of climate change must also be considered. Changes in sediment loads caused by anthopogenic impacts could, for example, be superimposed on changes associated with variation of the Southern Oscillation Index and associated shifts between El Nino and La Nina conditions, which would be likely to reduce the clarity of the signal generated by human impact. Where climate change results in an increased frequency of extreme events, this could have a very significant impact on sediment loads, since such events are commonly major contributors to the longer-term sediment flux.

\section{COMPLEXITIES IN THE RESPONSE OF SEDIMENT FLUXES TO GLOBAL CHANGE}

\section{Aggregation effects}

In many larger river basins, the key drivers of changing sediment load identified above will interact and the resultant signal, as reflected by the sediment load at the catchment outlet, could provide limited evidence of the changes occurring in the upstream basin. Thus, for example, increases in sediment load caused by land clearance in some parts of a river basin could be balanced by reductions in sediment load caused by dam construction on other tributaries or on the main river. Lu and Higgitt (1998) suggest that this is the situation in the Upper Yangtze River, in China, where increases in sediment load in some tributaries, caused by forest clearance and expansion of cultivated land, have been offset by reductions in the sediment load of other tributaries, as a result of dam construction and soil and water conservation programmes. As a result, the longer-term record of sediment load over the period 1950 to 1990 , for the main gauging station on the Upper Yangtze at Yichang, which drains a catchment of $1.005 .000 \mathrm{~km}^{2}$, shows no evidence of a statistically significant trend. The stationary character of the sediment record at Yichang has frequently been cited as evidence of a 'buffered' system, where, despite a major increase in population from ca 60 million in 1953 to ca 140 million in the 1990s, widespread forest clearance and the expansion of cultivated land, the sediment loads show little evidence of significant change (e.g. Dai and Tan 1996; Walling 2000). This 'buffering' would, however, seem to be primarily a reflection of the aggregation effects noted above.

\section{Storage and attenuation effects}

It is also important to recognise the potential importance of river floodplains and other sediment sinks, such as lakes, 
in more directly buffering the sediment response of large river basins and attenuating increases in sediment transport caused by human activity within the upstream catchment. A good example of changes in the signal generated by human impact, as it is transmitted through the lower reaches of a large river basin, is provided by the River $\mathrm{Ob}$, which drains a large $2.950 .000 \mathrm{~km}^{2}$ catchment in Siberia to the Arctic Ocean. The records of annual water discharge and suspended sediment load for the River $\mathrm{Ob}$ at Salekhard, the lowest monitoring station on this river, for the period 1936 to 2000 show no evidence of statistically significant trends and the double mass plot provides further evidence of a stable system. However, Bobrovitskaya et al. (1996) report that in this river basin the period 1957-1970 was characterised by significant human impact, both on the river channel and within the basin more generally, and cite an increase in the mean annual sediment load at Belgor'ye, some $700 \mathrm{~km}$ upstream of Salekhard, from ca. 19.2 Mt year ${ }^{-1}$ during the period 1938-1956, which was seen as representing the 'natural' regime, to $28.4 \mathrm{Mt} \mathrm{year}^{-1}$ during the period 1957-1990, an increase of almost $50 \%$. The lack of evidence of an increase in annual sediment load over the period of record at Salekhard can be attributed to overbank deposition on the $15000 \mathrm{~km}^{2}$ of well-developed floodplain that border the $870 \mathrm{~km}$ reach of the $\mathrm{Ob}$ River between Belegory'e and Salekhard. The significance of this deposition is clearly demonstrated by a comparison of the annual suspended sediment loads at Belegor'ye and Salekhard, with those of the latter currently being only about $50 \%$ of those of the former. This is despite an increase in catchment area of almost $10 \%$ and an increase in the annual runoff of about $25 \%$ between the two monitoring sites. Bobrovitskaya et al. (1996) suggest that the amounts of sediment deposited on the floodplain between Belegor'ye and Salekhard have increased more than threefold in recent years and it would seem that the increased deposition rates have effectively removed the signal of increasing sediment loads which is clearly apparent at Belegor'ye.

\section{CONCLUSIONS}

Despite the several uncertainties associated with identifying and interpreting recent trends in the suspended sediment loads of the world's rivers, it is clear that many of these rivers can be expected to show evidence of changing sediment loads in response to recent environmental change. For some rivers, loads will have increased due to human activity, particularly land clearance and catchment disturbance, whereas in others, loads will have decreased due to dam construction and the widespread introduction of soil conservation and sediment control programmes. In many river basins, the recent trend in sediment load will reflect the resultant of these two opposing controls, with the trend changing through time as the relative balance of the two controls shifts. Furthermore, in some river basins anthropogenic impacts will be combined with changes driven by recent climate change. It is important that the sensitivity of the sediment loads of rivers to recent environmental change should be recognised both in terms of the potential significance of these changes to the functioning of the Earth system, for example 
via geochemical cycling, as well as in relation to local and regional impacts and problems, such as the recession of delta shorelines due to the reduced sediment supply and the destruction of coral reefs due to increased sediment inputs to coastal seas.

\section{ACKNOWLEDGEMENTS}

This paper represents a contribution to the GEST (Global Evaluation of Sediment Transport) component of the UNESCO International Sedimentation Initiative (ISI). The help provided by Dr Don Fang with data analysis, and the generous assistance of many people and organisations, and particularly the International Research and Training Centre in Erosion and Sedimentation (IRTCES) in Beijing, China, Dr Nelly Bobrovitskaya from the State Hydrological Institute in St Petersburg, Russia, Professor John Milliman from the Virginia Institute of Marine Science, USA, Professor Juan Restrepo from EAFIT, Colombia and Professor Shuh-Ji Kao from the Research Center for Environmental Change, Academia Sinica, Taiwan, in providing sediment load data and background information, are very gratefully acknowledged.

\section{REFERENCES}

BOBROVITSKAYA N.M., ZUBKOVA C., MEADE R.H. 1996: Discharges and yields of suspended sediment in the $\mathrm{Ob}^{\prime}$ and Yenisey Riverrs of Siberia. In Walling D.E., Webb B.W. (Eds.), Erosion and Sediment Yield: Global and Regional Perspectives. (Proc. Exeter Symp.) IAHS Pub. No 236, IAHS Press, Wallingford, 115-123.

CHEN X., ZHOU Q., ZHANG E. 2006: In-channel sand extraction from the Mid-Lower Yangtze channels and its manaqgement problems and challenges. J. Environmental Planning and Management, 49, 309-320.

CHEN X. 2004: Sand extraction from the mid-lower Yangtze River channel and its impacts on sediment discharge into the sea. Proceedings, 9th International Symposium on River Sedimentation. Vol. 3, 1699-1704.

DAI D., TAN Y. 1996: Soil erosion and sediment yield in the Upper Yangtze River basin. In Walling, D.E. and Webb, B.W. (Eds.), Erosion and Sediment Yield: Global and Regional Perspectives. (Proc. Exeter Symp.), IAHS Pub. No 236, IAHS Press, Wallingford, 191-203.

GOLDEWIJK K.K. 2001: Estimating global land use change over the past 300 years: the HYDE Database. Global Biogeochemical Cycles, 15, 417-433.

KAO S-J., LEE T-Y., MILLIMAN J.D. 2005: Calculating highly fluctuated suspended sediment fluxes from mountainous rivers in Taiwan. Tao, $16,653-675$.

LU X.X., HIGGITT D.L. 1998: Recent changes of sediment yield in the Upper Yangtze, China. Environmental Management, 22, 697-709.

MARCHETTI M. 2002: Environmental changes in the central Po Plain (northern Italy) due to fluvial modifications and anthropogenic activities. Geomorphology, 44, 361-373.

MILLIMAN J.D., QURAISHEE G.S., BEG M.A.A. 1984: Sediment discharge from the Indus River to the Ocean: Past, present and future. In: Haq, B.U. and Milliman, J.D. (eds.) Marine Geology and Oceanography of Arabian Sea and Coastal Pakistan. Van Nostrand Rheinhold, New York, 65-70.

MILLIMAN J.H. AND SYVITSKI J.P.M. 1992: Geomorphic/Tectonic control of sediment discharge to the ocean: The importance of small mountainous rivers. J. Geology, 100, 325-344.

MORGAN R.P.C. 1986: Soil Erosion and Conservation. Longman, Harlow.

MORRIS G.L. 2003: Reservoir sedimentation management: Worldwide status and prospects. Paper presented at the Third World Water Forum, Otsu Siga, Japan, 2003.

MOU J. 1996: Recent studies of the role of soil conservation in reducing erosion and sediment yield in the loess plateau of the Yellow River basin. In Walling D.E. and Webb B.W. (Eds.), Erosion and Sediment Yield: Global and Regional Perspectives (Proc. Exeter Symp.) 
IAHS Pub. No 236, IAHS Press, Wallingford, 541-548.

PHILLIPS J.D., SLATTERY M.C., MUSSELMAN

Z.A. 2004: Dam-to-delta sediment inputs and storage in the Lower Trinity River, Texas. Geomorphology, 62, 17-34.

RESTREPO J.D., KJERFVE B. 2000: Magdalena

River: interannual variability (1975-1995) and revised water discharge and sediment load estimates. J. Hydrol., 235, 137-149.

ROPER J., ROBERTS R.W. 1999: Deforestation: tropical forests in decline. CFAN Forestry Issues Paper, CIDA, Forestry Advisers Network, Canada.

SHI C., ZHANG D., YOU L. 2002: Changes in sediment yield of the Yellow River basin of China during the Holocene. Geomorphology, 46, 2002, 267-2893.

STEFFEN W., SANDERSON A., TYSON P., JAGER J., MATSON P., MOORE B., OLDFIELD F., RICHARDSON K., SCHELLNHUBER H.J., TURNER B.L., WASSON R.J. 2004: Global Change and the Earth System: A Planet under Pressure. Springer-Verlag.

VÖRÖSMARTY C.J., MEYBECK M., FEKETE B., SHARMA K., GREEN P., SYVITSKI J.P.M. 2003: Anthropogenic sediment retenton: major global impact from registered river impoundments. Global and Planetary Change, 39, 169-190.

WALLING D.E. 1997: The response of sediment yields to environmental change. In Human Impact on Erosion and Sedimentation (Proc. Rabat Symp.) IAHS Pub. No 245, IAHS Press, Wallingford, p. 77-89.

WALLING D.E. 2000: Linking land use, erosion and sediment yields in river basins. Hydrobiol., 410, pp. 223-240.

WANG Z., LI Y., HE Y., 2007: Sediment budget of the Yangtze River. WaterResources Research. 43, W04401, doi:10.1029/2006WR005012
WHITE W.R. 2001: Evacuation of Sediments from Reservoirs. Thomas Telford Publishing, London.

WHITE W.R. 2005: World Water Storage in Man-Made Reservoirs: Review of Current Knowledge. Foundation for Water Research, Marlow, UK.

XU J.X. 2003: Sediment flux to the sea as influenced by changing human activities and precipitation: Example of the Yellow River, China. Environmental Management, 31, 328-341.

ZHAO W., JIAO E., WANG G., MENG X. 1992: Analysis on the variation of sediment yield in the Sanchuanhe river basin in 1980s. Internat. J. Sediment Res, 7, 1992, 1-19.

Streszczenie: Zmieniajqce się ładunki rumowiska rzek świata. W artykule przedstawiono dostępne informacje wskazujące na aktualne zmiany w ładunku rumowiska rzek świata oraz wskazano na podstawowe czynniki powodujące te zmiany. Wycinanie lasów, zmiany użytkowania terenu, a także inne działania związane zarówno $\mathrm{z}$ degradacja, jak i ochroną gruntów, oraz programy redukcji erozji gleb i budowa zapór, znacząco wpływają na ładunki rumowiska wielu rzek świata. Niektóre rzeki charakteryzują się znaczącym wzrostem ilości rumowiska, podczas gdy inne wskazują na znaczący ich spadek. Interpretacja wynikowych trendów wymaga rozważenia czynników mających cechy oddziaływania zagregowanego, opóźnionego i buforującego z całej zlewni, jako że informacje z ujściowych odcinków rzek nie w pełni odzwierciedlają zmiany zachodzące w górnej części rzeki i w jej dopływach.

\section{MS. received April 2008}

Author's address:

Amory Building, Rennes Drive, EXETER, Devon, EX4 4RJ, UK. e-mail: d.e.walling@exeter.ac.uk 